Population Study

Oral

Abstract ID: 7

\title{
Prevalence of cardiometabolic risk factors among Malaysian obese adults
}

Siti Zuhaidah Shahadan ${ }^{\mathrm{a}} \mid$ Azlina Daud $^{\mathrm{a}} \mid$ Muhammad Lokman Md Isa ${ }^{\mathrm{a}}$ | Samsul Deraman ${ }^{\mathrm{b}}$ | Muhammad Ibrahim $^{c}$

${ }^{a}$ Kulliyyah of Nursing, International Islamic University of Malaysia

${ }^{b}$ Kulliyyah of Medicine, International Islamic University Malaysia

'Kulliyyah of Allied Health Sciences, International Islamic University Malaysia

Introduction: Obese adults are associated with increased cardiometabolic risk (CMR). The study aims to investigate the prevalence of CMR factor abnormalities in obese adults in Kuantan. Methods: Seventy-six obese adults with a mean (standard deviation) age of 33.7 years (9.8 years) participated in this study. All participants had a waist circumference (WC) measured, blood pressure (BP) taken, and assessment of fasting blood glucose (FBG), lipid profile (LP) and high-sensitivity C-reactive protein (hs-CRP) level. Results: For CMR factors, the mean values for WC was $97.2 \pm 9.6 \mathrm{~cm}$, mean overall BP was $119 \pm 15 / 76 \pm 11 \mathrm{mmHg}$, mean FBG level was $4.8 \pm 0.5 \mathrm{mmol} / \mathrm{L}$ and the mean of total cholesterol (TC) and triglyceride (TG) was $5.4 \pm 1.0 \mathrm{mmol} / \mathrm{L}$ and $1.4 \pm 0.7 \mathrm{mmol} / \mathrm{L}$, respectively. Lastly, the mean of hs-CRP was $6.0 \pm 6.1 \mathrm{mg} / \mathrm{L}$. The CMR factors with the highest prevalence of abnormal values included WC (male 100\%; female 98\%) and TC (male 73.1\%; female 52\%) for both genders, systolic BP (50\%) and TG level $(61.5 \%)$ for male, and hs-CRP level $(68 \%)$ for female. Out of the nine CMR factors measured, five CMR risk factors were shown to have a high prevalence of abnormalities. Conclusions: The present study suggests that obese adults in Kuantan have multiple CMR factor abnormalities. A larger trial, sensibly informed of this trial, can now build upon and confirm these results.

KEYWORDS: obesity, adults, cardiometabolic risk factors 